University of Nebraska - Lincoln

DigitalCommons@University of Nebraska - Lincoln

$1-2007$

\title{
Disproportionate Relative Importance of a Terrestrial Beetle Family (Coleoptera: Scarabaeidae) as a Prey Source for Central Appalachian Brook Trout
}

\author{
Ryan M. Utz \\ University of Maryland,, rutz@al.umces.edu \\ Brett C. Ratcliffe \\ University of Nebraska-Lincoln, bratcliffe1@unl.edu \\ Brett T. Moore \\ West Virginia University \\ Kyle J. Hartman \\ West Virginia University
}

Follow this and additional works at: https://digitalcommons.unl.edu/entomologypapers

Part of the Entomology Commons

Utz, Ryan M.; Ratcliffe, Brett C.; Moore, Brett T.; and Hartman, Kyle J., "Disproportionate Relative Importance of a Terrestrial Beetle Family (Coleoptera: Scarabaeidae) as a Prey Source for Central Appalachian Brook Trout" (2007). Papers in Entomology. 135.

https://digitalcommons.unl.edu/entomologypapers/135

This Article is brought to you for free and open access by the Museum, University of Nebraska State at DigitalCommons@University of Nebraska - Lincoln. It has been accepted for inclusion in Papers in Entomology by an authorized administrator of DigitalCommons@University of Nebraska - Lincoln. 


\title{
Disproportionate Relative Importance of a Terrestrial Beetle Family (Coleoptera: Scarabaeidae) as a Prey Source for Central Appalachian Brook Trout
}

\author{
RYAN M. UTZ* \\ Appalachian Laboratory, University of Maryland, 301 Braddock Road, Frostburg, Maryland 21532, USA
}

\author{
BRetT C. RatClifFe \\ Systematics Research Collections, University of Nebraska, \\ W-436 Nebraska Hall, Lincoln, Nebraska 68588-0514, USA
}

\author{
Brett T. Moore and Kyle J. Hartman \\ Wildlife and Fisheries Resources Program, Division of Forestry and Natural Resources, \\ Davis College of Agriculture, Forestry, and Consumer Sciences, West Virginia University, \\ 320 Percival Hall, Morgantown, West Virginia 26506-6125, USA
}

\begin{abstract}
Brook trout Salvelinus fontinalis and other salmonids in Appalachia typically inhabit headwater watersheds, where food resources may limit growth. We monitored the feeding trends of a brook trout population in central Appalachia over the course of 2 years to determine variation in feeding intensity and important prey items. One terrestrial beetle family, Scarabaeidae, provided a disproportionate amount of energy during the only time of year when brook trout were feeding substantially above maintenance ration. Scarab beetles contributed $39.6 \%$ of all energy consumed during May and June of both years, though the number of fish with one or more scarabaeids present in the stomach varied by month $(22.2-51.7 \%)$. The species composition of scarab beetles consumed suggested that four species are of particular importance. Our findings imply that scarabaeids represent a considerably important prey taxon for brook trout in the region. Considering the foraging habits of the scarabaeid species in question, the phenomenon we witnessed probably occurs throughout Appalachia.
\end{abstract}

Lotic salmonids in low-productivity headwater watersheds typically experience poor feeding conditions, though the consumption of terrestrial organisms may improve energy intake. The most frequently cited source of nutrients in headwater streams is input of allochthonous forest material from the surrounding watershed, which provides energy to an invertebrate community (Vannote et al. 1980). This aquatic invertebrate community is the most commonly cited source of energy for top predators in streams, such as salmonids (Neveu 1999). However, recent examinations of salmonid diets in headwater watersheds reveal that terrestrial organisms may outweigh aquatic

* Corresponding author: rutz@al.umces.edu

Received March 7, 2006; accepted September 21, 2006 Published online January 29, 2007 organisms in energy provided to fish (Kawaguchi and Nakano 2001; Sweka and Hartman, in press; Utz and Hartman 2007). When taxonomic detail of terrestrial invertebrates is considered relative to nutrient input to streams, ecosystems, and salmonid diet, results suggest that certain organisms are of particular importance while others are of negligible importance (Allan 1981; Nielsen 1992; Wipfli and Gregovich 2002; Utz and Hartman 2007). Despite the notion that a variety of terrestrial organisms may be of critical importance to lotic salmonids, a large number of salmonid diet studies classify all terrestrial organisms into one broad category (Cada et al. 1987; Forrester et al. 1994; Bridcut and Giller 1995; Mookerji et al. 2004). The growing understanding that salmonids may be heavily dependent on certain terrestrial organisms merits more attention to the species composition of terrestrial organisms in their diets.

In Appalachia, salmonids must cope with periodically poor feeding conditions (Cada et al. 1987; Ensign et al. 1990; Sweka 2003; Thorne 2004) as well as occasional extreme environmental circumstances, such as drought and flooding (Carline and McCullough 2003; Hakala and Hartman 2004). The low productivity of Appalachian headwater watersheds, coupled with natural environmental variability, may affect the population dynamics and growth patterns of salmonids. The current study complements a 2-year observational analysis of temporal feeding trends of adult Appalachian brook trout Salvelinus fontinalis (Utz and Hartman 2006, 2007). These studies found that brook trout only exceed maintenance energy rations consistently and substantially during the spring (May and June). One family of terrestrial beetles, Scarabaeidae (hereafter, scarabaeids), emerged as one of the most important prey taxa for the population we studied 
during this important season. The purpose of this paper is to demonstrate the substantial importance of scarabaeids to Appalachian brook trout and discuss factors that may affect the availability of this prey.

\section{Methods}

The study was conducted within the Middle Fork River watershed, a north-flowing tributary of the Tygart River in the central Appalachian Mountains of Randolph County, West Virginia. The majority of land cover within the watershed is secondary-growth hardwood (mostly beeches Fagus spp., birches Betula spp., cherries Prunus spp., and maples Acer spp.) deciduous forest (Keyser and Ford 2005). All sites in the study are located in the southernmost extent of the watershed and are of low order and high gradient; they are therefore typical of Appalachian brook trout streams (Jenkins and Burkhead 1994). Sites (9-200 m) were selected based on a number of criteria: each site contained a resident brook trout population, consistently supported age- 0 brook trout (suggesting that physiochemical conditions were adequate for spawning), and was devoid of fish barriers between other sites. The entire study watershed is located within the MeadWestvaco Wildlife and Ecosystem Research Forest. For a detailed description of the watershed area, including a description of forest cover, see Keyser and Ford (2005).

Fish sampling occurred 11 times over the course of 2 years in 2004 and 2005; sampling took place over 2-5 $\mathrm{d}$ during the middle of the month. Sampling was conducted between 0800 and 1600 hours, and the order in which sites were sampled was randomly chosen. Sampling teams used an electrofishing unit (SmithRoot, Inc., Vancouver, Washington; DC, $60 \mathrm{~Hz}, 500$ $750 \mathrm{~V}$ ) and dip nets to capture fish.

After collection, fish were processed at a streamside station. All fish were immobilized with a clove oil and 95\% ethanol solution. Brook trout were weighed to the nearest $0.5 \mathrm{~g}$; total length was measured to the nearest millimeter. Subsets of 10 brook trout per site per month were chosen for stomach content removal. Because of gear restrictions, only fish larger than $110 \mathrm{~mm}$ total length were considered eligible for gut content removal; the 7-mm-diameter tube used in flushing water into the gut was usually larger than the gapes of fish smaller than $110 \mathrm{~mm}$. The fish that were analyzed generally represented ages 1 and older (Utz 2005), and the total length ranged from 110 to $259 \mathrm{~mm}$. Following the protocol of Twomey and Giller (1990), stomach contents were removed by directing a constant flow of stream water into the foregut until all items were collected. Gut items were filtered with a $250-\mu \mathrm{m}$ sieve and transferred to $95 \%$ ethanol.
All prey items were identified to the family level where possible, or to the lowest taxonomic rank to quantify prey exploitation by frequency and energy. The exceptions were scarabaeids, which were identified to genus or species. Extremely small organisms $(<0.5 \mathrm{~mm}$ in length) or organisms that were substantially destroyed were identified to order. The lengths of prey items were measured via an ocular micrometer to the nearest $0.1 \mathrm{~mm}$; when lengths were unavailable, head capsule widths were measured to the nearest 0.1 $\mathrm{mm}$. Carapace lengths of Appalachian brook crayfish Cambarus bartonii were measured instead of head capsule width or body length. The dry mass of each organism was estimated with the use of published length-dry mass or head width-dry mass equations, except for crayfish, where a carapace-dry mass equation was used (Sample et al. 1993; Benke et al. 1999; Johnston and Cunjak 1999; Sabo et al. 2002). Using lengths and head widths to estimate weights allowed for approximation of weight when prey items were partially destroyed. Vertebrate food items, such as frogs (e.g., family Anura), salamanders (family Plethodontidae), and fish, were dried at a temperature of $60^{\circ} \mathrm{C}$ for $48 \mathrm{~h}$ to calculate dry weight. Each prey item was converted to energy content with the use of dry weight-energy equations (Cummins and Wuycheck 1971), and the total energy in the gut was summarized for each fish.

Mean maintenance ration and observed daily ration were calculated for each month to gauge how successful brook trout were in meeting metabolic demands over the course of the study. Estimated maintenance rations $\left(\mathrm{J} \cdot \mathrm{g}\right.$ fish wet weight ${ }^{-1} \cdot \mathrm{d}^{-1}$ ) were calculated based on a bioenergetics model for brook trout (Hartman and Sweka 2003) that used fish weight, fish energy density, and observed water temperature as variables. Maintenance ration was determined by calculating the energy required to maintain zero growth over the course of a day. Energy densities were either calculated from observed mean energy density in collected fish by use of a salmonid dry weight-energy equation (Hartman and Brandt 1995) or interpolated from energy densities taken before and after a given collection period. Daily ration values were calculated using summarized prey energy per fish and the gastric evacuation rate. The total energy observed in a stomach sample was multiplied by the brook trout gastric evacuation rate (based on temperature; Sweka et al. 2004) and divided by fish weight to calculate an observed consumption value (J.g fish wet weight ${ }^{-1} \cdot \mathrm{h}^{-1}$ ) as suggested by Eggers (1977). This estimate was multiplied by 24 to convert it to a daily ration. Individual parameters of the brook trout bioenergetics model can be found in Hartman and Sweka (2003). 
TABLE 1.-Top prey taxa consumed by brook trout in the Middle Fork River watershed, West Virginia (total energy consumed), during May and June, 2004 and 2005. The commonly encountered scarabaeids are listed by genus and species; all other prey taxa are displayed by order or class. The number of times an individual from a prey group was encountered across all sites in all sampled fish $(n)$ is also provided.

\begin{tabular}{lrcc}
\hline \multicolumn{1}{c}{ Taxon } & $\begin{array}{c}\text { Number } \\
\text { consumed }\end{array}$ & $\begin{array}{c}\text { Energy } \\
\text { consumed (J) }\end{array}$ & $\begin{array}{c}\text { Percentage of total } \\
\text { energy consumed }\end{array}$ \\
\hline Coleoptera & 1,874 & 975,087 & 54.2 \\
Scarabaeidae & 286 & 710,986 & 39.6 \\
$\quad$ Phyllophaga longispina & 58 & 304,614 & 16.8 \\
P. anxia & 25 & 168,870 & 9.3 \\
$\quad$ Serica atracapilla & 127 & 168,731 & 9.3 \\
$\quad$ Dichelonyx diluta & 43 & 51,565 & 2.8 \\
Non-Scarabaeidae & 1,589 & 264,101 & 14.6 \\
Diptera & 4,589 & 270,379 & 14.9 \\
Hymenoptera & 566 & 87,848 & 4.9 \\
Plecoptera & 401 & 80,200 & 4.4 \\
Lepidoptera & 180 & 73,523 & 4.1 \\
Diplopoda & 32 & 68,274 & 3.8 \\
Blattaria & 7 & 50,928 & 2.8 \\
\hline
\end{tabular}

Though daily consumption typically requires estimates of feeding activity across a diel cycle (Bowen 1996), multiple studies of brook trout feeding trends revealed no significant diel pattern in multiple diet variables (Forrester et al. 1994; Sweka 2003; Mookerji et al. 2004). Further, the evacuation rate of brook trout has proven to be low relative to rates exhibited by other salmonids (Sweka et al. 2004), which means that food items remain in the gut long after they have been ingested. Thus, we assumed that a measurement of diet during daylight hours provided sufficient data to calculate typical feeding conditions for the corresponding season.

Related studies (Utz and Hartman 2006) revealed that spring and early summer (May and June) were the most productive periods for feeding by Middle Fork River brook trout. Upon examination of stomach contents during these months, it became apparent that brook trout consumed large numbers of scarabaeids. To examine the importance of scarabaeids relative to that of other prey categories, the total energy derived from scarabaeids was compared with the combined energy provided by other prey taxa (order level) during May and June of both study years. Further, the mean number of prey items per brook trout and the mean energy content per prey item for each family were calculated for comparison among prey families. A number of metrics are designed to demonstrate prey importance, but each has an inherent disadvantage (Chipps and Garvey, in press). In highlighting the substantial energy gained by the brook trout population as a whole, no real statistical comparisons were necessary.

\section{Results}

Adult scarabaeids contributed the greatest amount of energy consumed by brook trout during May and June
(Table 1). Throughout the study, seven scarabaeid taxa were identified: Phyllophaga longispina, P. anxia, Serica atracapilla, Hoplia trivialis, Dichelonyx diluta (all in the subfamily Melolonthinae; leaf chafers), Aphodius spp., and Ataenius spp. (both in the subfamily Aphodiinae; small dung beetles). When the energy consumed by brook trout during May and June of both years was totaled, scarabaeids contributed a proportionally greater amount than any other prey taxon, while $P$. longispina contributed more than any taxon (Table 1). The number of fish with scarabaeids in the gut varied between months and ranged from $22.2 \%$ to $51.7 \%$ (Table 2). Scarabaeids were rarely seen in the diet after June. The importance of scarabaeids is apparent when the daily ration of brook trout with scarabaeids present in their stomachs is compared with that of brook trout that did not consume scarabaeids (Figure 1).

While the energy derived from scarabaeids remained high throughout the spring and early summer, the contribution of individual species varied between months. When the energy was summed for each scarabaeid species and compared with that of the other prey taxa, the ranks held by scarabaeid species varied among the months (Table 3). However, the highest

TABLE 2.-Number of brook trout sampled for gut contents and percentage of brook trout that consumed scarabaeid beetles in May and June of 2004 and 2005 in the Middle Fork River, West Virginia.

\begin{tabular}{lcc}
\hline Month and year & Fish $(n)$ & Percentage that consumed scarabaeids \\
\hline May 2004 & 87 & 51.7 \\
Jun 2004 & 84 & 45.2 \\
May 2005 & 90 & 37.8 \\
Jun 2005 & 90 & 22.2 \\
\hline
\end{tabular}




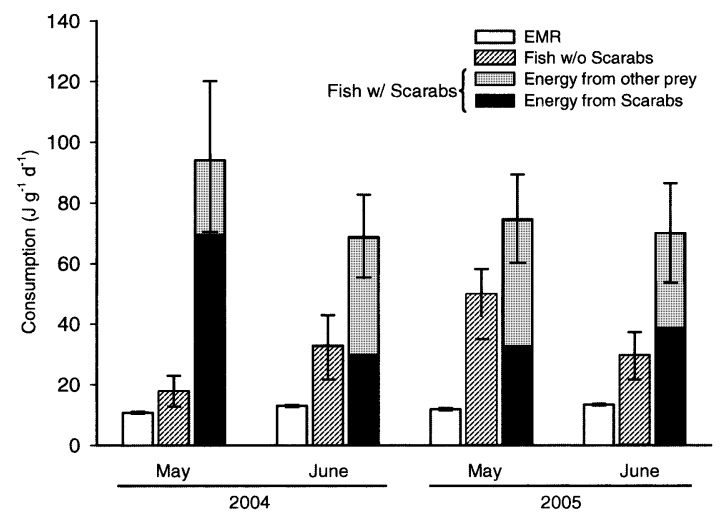

FIGURE 1.-Mean monthly estimated maintenance ration (EMR) and observed consumption values for brook trout with at least one scarab beetle present in the stomach and brook trout with no scarabaeids present; fish were sampled in 2004 and 2005 within the Middle Fork River watershed, West Virginia. The column representing brook trout that consumed one or more scarabaeids is divided into mean energy provided by scarabaeids and other prey sources. Error bars represent 95\% confidence intervals for the entire column (not delineated prey sources).

ranks among the scarabaeids were held by four species: $P$. longispina, $P$. anxia, S. atracapilla, and D. diluta. When the energy provided by all scarabaeid species was combined, the resulting energy outweighed that of all other prey taxa; this occurred because the summed energy from scarabaeids was consistently higher than the summed energy from other taxa, as visible in Figure 1.

For all months (except May 2004), no single scarabaeid species was ranked as the most important prey item, but the entire family ranked very high in both frequency of occurrence in brook trout stomachs and in mean energy provided per capture. As a family, scarabaeids ranked second for frequency of occurrence and fourth for mean energy provided per prey item relative to other prey taxa (Table 4).

\section{Discussion}

The finding that scarabaeids provide a disproportionate amount of energy to Middle Fork River brook trout suggests that a select few terrestrial beetles outweigh most other prey organisms in importance, especially during the spring and early summer emergence of a few key adult scarabaeids. The concept of a single family or species of terrestrial insect contributing such a consistent and large proportion of energy to a trout species' diet is novel. A number of studies have shown terrestrial organisms to be of great importance in Japanese (Nakano et al. 1999; Kawaguchi and Nakano 2001; Kawaguchi et al. 2003), Alaskan (Wipfli 1997) and eastern United States streams (Forrester et al. 1994; Utz and Hartman 2007; Sweka and Hartman, in press). However, few researchers have identified a specific family or species of terrestrial organism that provides a large amount of energy as consistently as do the scarabaeids in the Middle Fork River watershed. When taxonomic detail has been applied to terrestrial organisms in salmonid diets, terrestrial beetles usually emerge as very important (Allan 1981; Wipfli 1997; Kawaguchi and Nakano 2001; Utz and Hartman 2007). In a nearby watershed, Sweka (2003: Appendix A) found that scarabaeids contributed as much as $63 \%$ of the total ingested prey weight for brook trout populations. While prey weight does not directly correlate to energy content, such a finding may suggest a level of scarabaeid consumption in excess of that in the current study. Besides Sweka (2003), we could locate only one other literature report of scarabaeids as important salmonid prey, and this was anecdotal (Ratcliffe and Ocampo 2002). Unfortunately, a typical approach in

TABLE 3.- Ranked energy contribution made by the family Scarabaeidae and scarabaeid species to the diet of brook trout in the Middle Fork River watershed, West Virginia, in May and June, 2004-2005. The total number of prey categories $(N)$ refers to the number of scarabaeid species and other prey taxa (by order) encountered in diets in the corresponding month. Rankings are in relation to all other prey categories.

\begin{tabular}{lcccc}
\hline \multicolumn{1}{c}{ Category or taxon } & $\begin{array}{c}\text { May 2004 } \\
(N=30)\end{array}$ & $\begin{array}{c}\text { Jun 2004 } \\
(N=27)\end{array}$ & $\begin{array}{c}\text { May 2005 } \\
(N=25)\end{array}$ & $\begin{array}{r}\text { Jun 2005 } \\
(N=29)\end{array}$ \\
\hline Scarabaeidae & 1 & 1 & 1 & 1 \\
$\quad$ Phyllophaga longispina & 1 & 6 & 4 & 6 \\
$P$. anxia & 2 & 8 & 10 & 7 \\
Serica atracapilla & 3 & 10 & 3 & 5 \\
Dichelonyx diluta & 9 & 4 & $\mathrm{n} / \mathrm{a}$ & 21 \\
Aphodius spp. & 26 & $\mathrm{n} / \mathrm{a}$ & 22 & $\mathrm{n} / \mathrm{a}$ \\
Ataenius spp. & 23 & $\mathrm{n} / \mathrm{a}$ & 16 & $\mathrm{n} / \mathrm{a}$ \\
Hoplia trivialis & $\mathrm{n} / \mathrm{a}$ & 24 & 24 & $\mathrm{n} / \mathrm{a}$ \\
Unidentifiable & 16 & 13 & 18 & $\mathrm{n} / \mathrm{a}$ \\
\hline
\end{tabular}


TABLE 4.- Top 10 prey families consumed by brook trout, based on mean number per fish and mean energy content per capture, during May and June of 2004 and 2005, in the Middle Fork River watershed, West Virginia.

\begin{tabular}{llccr}
\hline \multicolumn{1}{c}{ Order } & \multicolumn{1}{c}{ Family } & Count & Mean number per fish & Mean energy (J) \\
\hline & \multicolumn{4}{c}{ Ranking by energy } \\
Blattaria & Cryptocercidae & 6 & 0.0170 & \\
Anura & Hylidae & 1 & 0.0028 & $6,702.1$ \\
Scorpaeniformes & Cottidae & 6 & 0.0170 & $3,687.0$ \\
Coleoptera & Scarabaeidae & 286 & 0.8125 & $3,108.4$ \\
Hemiptera & Pentatomidae & 8 & 0.0227 & $2,539.0$ \\
Coleoptera & Bupestridae & 1 & 0.0028 & $2,485.3$ \\
Odonata & Gomphidae & 4 & 0.0114 & $2,004.4$ \\
Hymenoptera & Apidae & 3 & 0.0085 & $1,728.7$ \\
Orthoptera & Acrididae & 10 & 0.0284 & $1,646.1$ \\
Plecoptera & Pteronarcyidae & 52 & 0.1477 & $1,153.9$ \\
& & & & $1,029.6$ \\
Diptera & Empididae & 1,835 & 5.2131 & \\
Coleoptera & Scarabaeidae & 286 & 0.8125 & 49.4 \\
Hemiptera & Cydnidae & 278 & 0.7898 & $2,539.0$ \\
Coleoptera & Scolytidae & 268 & 0.7614 & 8.2 \\
Hymenoptera & Formicidae & 251 & 0.7131 & 19.0 \\
Coleoptera & Chrysomelidae & 249 & 0.7074 & 72.0 \\
Coleoptera & Staphylinidae & 208 & 0.5909 & 254.4 \\
Diptera & Tipulidae & 191 & 0.5426 & 66.3 \\
Trichoptera & Limnephilidae & 187 & 0.5313 & 187.2 \\
Coleoptera & Curculionidae & 169 & 0.4801 & 41.8 \\
\hline
\end{tabular}

descriptive studies of salmonid diets has been to classify all terrestrial organisms into a single, broad category (Cada et al. 1987; Forrester et al. 1994; Bridcut and Giller 1995; Nakano et al. 1999; Mookerji et al. 2004). While we previously reported moderate terrestrial taxonomic analysis in a related study (Utz and Hartman 2007), the current study suggests that careful analysis of terrestrial taxonomic detail in fish diets reveals important ecological phenomena.

Though we made a number of assumptions, we feel that no associated error would affect our general findings. Scarabaeids possess a number of hard parts (i.e., elytra, head, and thorax), but beetles were not counted unless all nonextraneous body parts were present in the sample. Further, a number of other common prey contained hard parts (trichopteran cases, hard parts of other beetles, vertebrate skeletons, crayfish carapaces), yet such prey did not dominate the diet as did scarabaeids. Sampling during daylight hours may have skewed some dietary proportions, despite the low gastric evacuation rate of brook trout (Sweka et al. 2004). However, most scarabaeids are nocturnally active; therefore, our potential bias would favor a diminished importance of scarabaeids as prey. We assumed that all items were collected from brook trout stomachs, and we did not use a correction factor to account for retention of food items by sampled fish. Our approach has proven $98 \%$ (Light et al. 1983) effective in removing items from brook trout stomachs. Food items were detectable by touch, and flushing was performed several seconds after all detectable items had been removed. Therefore, any remaining items would probably have been small and thus low in energetic importance.

The nature of the riparian zone (vegetation composition and other physical features) may influence which organisms fall into the stream and provide energy to aquatic predators and scavengers. This has been shown in a number of cases (Wipfli 1997; Kawaguchi and Nakano 2001; Allan et al. 2003). Four species in the subfamily Melolonthinae (leaf chafers) stand out as most important to Middle Fork River brook trout: $P$. longispina, $P$. anxia, S. atracapilla, and D. diluta. Both Phyllophaga species are large beetles (approximately $17.0-25.0 \mathrm{~mm}$ in length). The adult stages of these species emerge in the spring (late March for $P$. anxia and mid-May for $P$. longispina) and cease activity by July. Both $S$. atracapilla and $D$. diluta are smaller species (approximately 11.5 and $10.0 \mathrm{~mm}$, respectively) whose adult activity peaks in the spring and early summer. The dietary requirements of these scarabaeids (Table 5) reflect the vegetative composition in the watershed. With the exception of $D$. diluta, all feed exclusively on the leaf material of deciduous trees and perennial shrubs. The study area is dominated by beeches, birches, cherries, and maples, while oaks and American basswood may be found in lower elevations in the research forest (Keyser and Ford 2005). We suggest that these scarabaeid species are important prey organisms for other brook trout populations, as the Middle Fork River watershed forest composition is typical for much of the eastern brook trout range (Hicks 
TABLE 5.-Forage foliage used by the four scarabaeid species that were most important in the diet of Middle Fork River (West Virginia) brook trout (Luginbill and Painter 1953; Cornell 1972; McCutcheon et al. 1994; P. Lago, University of Mississippi, personal communication).

\begin{tabular}{|c|c|c|c|c|}
\hline Tree or shrub & Phyllophaga longispina & P. anxia & Serica atracapilla & Dichelonyx diluta \\
\hline American basswood Tilia americana & & + & & \\
\hline American beech Fagus grandifolia & + & + & & \\
\hline Birches & & + & & + \\
\hline Dogwoods Cornus spp. & + & + & & \\
\hline Elms Ulmus spp. & + & + & + & \\
\hline American hazelnut Corylus Americana & & & + & \\
\hline Shellbark hickory Carya laciniosa & & & + & \\
\hline Honeysuckles Lonicera spp. & & + & & \\
\hline Maples & + & + & + & \\
\hline Oaks Quercus spp. & & & + & + \\
\hline Pines Pinus spp. & & & & + \\
\hline Rose Rosa spp. & + & + & + & + \\
\hline Black walnut Juglans nigra & + & + & & \\
\hline Willows Salix spp. & & + & & + \\
\hline Witchhazels Hamamelis spp. & + & + & & \\
\hline
\end{tabular}

1998). Further, the range of the four important scarabaeids identified in our study overlaps broadly with the range of brook trout in the eastern United States (Table 6).

The life history and behavior of adult scarabaeids probably affect how brook trout acquire this particular prey. Most adult melolonthines are nocturnally active. They often accidentally fall into the water while flying or while feeding or resting on overhanging vegetation. Adult emergences of these species are frequently large, so they provide a seasonally abundant food source. The presence of suitable riparian habitat that supports an array of host plants for the beetles is almost certainly important for maintaining their populations as a food resource.

The substantial importance of scarabaeids to brook trout in the Middle Fork River watershed would probably be observed elsewhere. As a result, future studies considering brook trout feeding ecology in watersheds with similar forest structure should consider the potential of this trend.

\section{Acknowledgments}

This study was funded by MeadWestvaco, the West Virginia Division of Natural Resources, the U.S. Forest

TABLE 6.-Geographic ranges of the four scarabaeid species that were most important in the diet of Middle Fork River (West Virginia) brook trout (Luginbill and Painter 1953; Blackwelder and Arnett 1974).

\begin{tabular}{lc}
\hline \multicolumn{1}{c}{ Species } & \multicolumn{1}{c}{ Geographic range } \\
\hline Phyllophaga longispina & Eastern USA; Ontario to Georgia and \\
& west to Illinois \\
$P$. anxia & Nearly the entire USA, except the \\
& Southwest and California \\
Serica atricapilla & Eastern USA \\
Dichelonyx diluta & Northeastern and north-central USA \\
\hline
\end{tabular}

Service's Monongahela National Forest and Northeastern Experiment Station, and a National Science Foundation Partnerships for Enhancing Expertise in Taxonomy grant (DEB 0118669) to M. L. Jameson and B.C.R. Care and handling of all fish were completed in accordance with approved protocols filed with the West Virginia University Animal Care and Use Committee. The authors thank Paul Lago (University of Mississippi) and Art Evans (Richmond, Virginia) for assistance with locality records and literature.

\section{References}

Allan, J. D. 1981. Determinants of diet of brook trout (Salvelinus fontinalis) in a mountain stream. Canadian Journal of Fisheries and Aquatic Sciences 38:184-192.

Allan, J. D., M. S. Wipfli, J. P. Caouette, A. Prussian, and J. Rodgers. 2003. Influence of streamside vegetation on inputs of terrestrial invertebrates to salmonid food webs. Canadian Journal of Fisheries and Aquatic Sciences 60:309-320.

Benke, A. C., A. D. Huryn, L. A. Smock, and J. B. Wallace. 1999. Length-mass relationships for freshwater macroinvertebrates in North America with particular reference to the southeastern United States. Journal of the North American Benthological Society 18:308-343.

Blackwelder, R. E., and R. H. Arnett. 1974. Checklist of the beetles of Canada, United States, Mexico, Central America, and the West Indies, volume 1, part 3. The scarab beetles, ant-loving beetles, clown beetles, and related groups. Biological Research Institute of America, Latham, New York.

Bowen, S. H. 1996. Quantitative description of the diet. Pages 513-529 in B. R. Murphy and D. W. Willis, editors. Fisheries techniques, 2nd edition. American Fisheries Society, Bethesda, Maryland.

Bridcut, E. E., and P. S. Giller. 1995. Diet variability and foraging strategies in brown trout (Salmo trutta): an analysis from subpopulations to individuals. Canadian Journal of Fisheries and Aquatic Sciences 52:2543-2552. Cada, G. F., J. M. Loar, and M. J. Sale. 1987. Evidence of 
food limitation of rainbow and brown trout in southern Appalachian soft-water streams. Transactions of the American Fisheries Society 116:692-702.

Carline, R. F., and B. J. McCullough. 2003. Effects of floods on brook trout populations in the Monongahela National Forest, West Virginia. Transactions of the American Fisheries Society 132:1014-1020.

Chipps, S. R., and J. E. Garvey. In press. Assessment of food habits and feeding patterns. In $\mathrm{M}$. Brown, editor. Analysis and interpretation of freshwater fisheries data. American Fisheries Society, Bethesda, Maryland.

Cornell, J. F. 1972. A taxonomic revision of the beetle genus Dichelonyx Harris in North America (Scarabaeidae: Melolonthinae). Doctoral dissertation. Oregon State University, Corvallis.

Cummins, K. C., and J. C. Wuycheck. 1971. Caloric equivalents for investigations in ecological energetics. Mitteilungen der Internationalen Vereinigung fuer Theoretische und Angewandte Limnologie 18:1-158.

Eggers, D. M. 1977. Factors in interpreting data obtained by diel sampling of fish stomachs. Journal of the Fisheries Research Board of Canada 34:290-294.

Ensign, W. E., R. J. Strange, and S. E. Moore. 1990. Summer food limitation reduces brook and rainbow trout biomass in a southern Appalachian stream. Transactions of the American Fisheries Society 119:894-901.

Forrester, G. E., J. G. Chace, and W. McCarthy. 1994. Diel and density-related changes in food consumption and prey selection by brook charr in a New Hampshire stream. Environmental Biology of Fishes 39:301-311.

Hakala, J. P., and K. J. Hartman. 2004. Drought effect on stream morphology and brook trout (Salvelinus fontinalis) populations in forested headwater streams. Hydrobiologia 515:203-213.

Hartman, K. J., and S. B. Brandt. 1995. Estimating energy density in fish. Transactions of the American Fisheries Society 124:347-355.

Hartman, K. J., and J. A. Sweka. 2003. Development of a bioenergetics model for Appalachian brook trout. Proceedings of the Annual Conference Southeastern Association of Fish and Wildlife Agencies 55(2001):3851.

Hicks, R. 1998. Ecology and management of central hardwood forests. Wiley, New York.

Jenkins, R. E., and N. M. Burkhead. 1994. Freshwater fishes of Virginia. American Fisheries Society, Bethesda, Maryland.

Johnston, T. A., and R. A. Cunjak. 1999. Dry mass-length relationships for benthic insects: a review with new data from Catamaran Brook, New Brunswick, Canada. Freshwater Biology 41:653-674.

Kawaguchi, C., Y. Taniguchi, and S. Nakano. 2003. Terrestrial invertebrate inputs determine the local abundance of stream fishes in a forested stream. Ecology 84:701-708.

Kawaguchi, Y., and S. Nakano. 2001. Contribution of terrestrial invertebrates to the annual resource budget for salmonids in forest and grassland reaches of a headwater stream. Freshwater Biology 46:303-316.

Keyser, P. D., and W. M. Ford. 2005. Ten years of research on the MeadWestvaco wildlife and ecosystem research forest: an annotated bibliography. U.S. Department of
Agriculture Forest Service General Technical Report NE-330. Available: http://www.fs.fed.us/ne/newtown square/publications/technical_reports/pdfs/2005/ ne_gtr330.pdf7. (November 2006).

Light, R. W., P. H. Adler, and D. Arnold. 1983. Evaluation of gastric lavage for stomach analyses. North American Journal of Fisheries Management 3:81-85.

Luginbill, P., and H. R. Painter. 1953. May beetles of the United States and Canada. U.S. Department of Agriculture Technical Bulletin 1060:1-102.

McCutcheon, T. W., J. E. Weaver, and M. C. Thomas. 1994. An annotated checklist of West Virginia May or June beetles (Coleoptera: Scarabaeidae: Phyllophaga spp.). Insecta Mundi 8:247-249.

Mookerji, N., Z. Weng, and A. Mazumder. 2004. Food partitioning between coexisting Atlantic salmon and brook trout in the Sainte-Marguerite River ecosystem, Quebec. Journal of Fish Biology 64:680-694.

Nakano, S., H. Miyasaka, and N. Kuhara. 1999. Terrestrialaquatic linkages: riparian arthropod inputs alter trophic cascades in a stream food web. Ecology 80:2435-2441.

Neveu, A. 1999. Feeding strategy of the brown trout (Salmo trutta L.) in running water. Pages 91-113 in J. L. Bagliniere and G. Maisse, editors. Biology and ecology of the brown and sea trout. Springer, Chichester, UK.

Nielsen, J. L. 1992. Microhabitat-specific foraging behavior, diet, and growth of juvenile coho salmon. Transactions of the American Fisheries Society 121:617-634.

Ratcliffe, B. C., and F. C. Ocampo. 2002. A review of the genus Hylamorpha Arrow (Coleoptera: Scarabaeidae: Rutelinae: Anoplognathini: Brachysternina). Coleopterists Bulletin 56:367-378.

Sabo, J. L., J. L. Bastow, and M. E. Power. 2002. Lengthmass relationships for adult aquatic and terrestrial invertebrates in a California watershed. Journal of the North American Benthological Society 21:336-343.

Sample, B. E., R. J. Cooper, R. D. Greer, and R. C. Whitmore. 1993. Estimation of insect biomass by length and weight. American Midland Naturalist 129:234-240.

Sweka, J. A. 2003. Aquatic-terrestrial linkages in Appalachian streams: influence of riparian inputs on stream habitat, brook trout populations, and trophic dynamics. Doctoral dissertation. West Virginia University, Morgantown. Available: http://kitkat.wvu.edu:8080/files/3157/ Sweka_John_Dissertation.pdf.8. (November 2006).

Sweka, J. A., M. K. Cox, and K. J. Hartman. 2004. Gastric evacuation rates of brook trout. Transactions of the American Fisheries Society 133:204-210.

Sweka, J. A., and K. J. Hartman. In press. Contribution of terrestrial invertebrates to yearly brook trout prey consumption and growth. Transactions of the American Fisheries Society.

Thorne, D. W. 2004. Spatial and seasonal variation in brook trout diet, growth, and consumption in a complex Appalachian watershed. Master's thesis. West Virginia University, Morgantown.

Twomey, H., and P. S. Giller. 1990. Stomach flushing and individual Panjet tattooing of salmonids: an evaluation of the long-term effects on two wild populations. Aquaculture and Fisheries Management 21:137-142.

Utz, R. M. 2005. Temporal trends in consumption, growth, and successful feeding traits of a central Appalachian 
brook trout population at the watershed scale. Master's thesis. West Virginia University, Morgantown. Available: http://kitkat.wvu.edu:8080/files/4327/Utz_Ryan_ thesis.pdf9. (November 2006).

Utz, R. M., and K. J. Hartman. 2006. Temporal and spatial variation in the energy intake of a brook trout (Salvelinus fontinalis) population in an Appalachian stream. Canadian Journal of Fisheries and Aquatic Sciences 63:26752686

Utz, R. M., and K. J. Hartman. 2007. Identification of critical prey items to Appalachian brook trout (Salvelinus fontinalis) with emphasis on terrestrial organisms. Hydrobiologia 575:259-270.

Vannote, R. L., G. W. Minshall, K. W. Cummins, J. R. Sedell, and C. E. Cushing. 1980. The river continuum concept. Canadian Journal of Fisheries and Aquatic Sciences 37:130-137.

Wipfli, M. S. 1997. Terrestrial invertebrates as salmonid prey and nitrogen sources in streams: contrasting old-growth and young-growth riparian forests in southeastern Alaska, USA. Canadian Journal of Fisheries and Aquatic Sciences 54:1259-1269.

Wipfli, M. S., and D. P. Gregovich. 2002. Export of invertebrates and detritus from fishless headwater streams in southeastern Alaska: implications for downstream salmonid production. Freshwater Biology 47:957-969. 